POLSKA AKADEMIA UMIEJĘTNOŚCI

ELŻBIETA Ż̇A

Uniwersytet Jagielloński

\title{
ROLA POWIEŚCI KRYMINALNEJ WE WSPÓŁCZESNEJ ROSYJSKIEJ KULTURZE MASOWEJ
}

\author{
THE PLACE OF A DETECTIVE FICTION \\ IN THE CONTEMPORARY RUSSIAN MASS CULTURE
}

\begin{abstract}
Streszczenie
Celem artykułu jest zwrócenie uwagi na specyfikę rozwoju i sposób funkcjonowania powieści kryminalnej początkowo w Związku Radzieckim, obecnie - w Rosji. We współczesnej Rosji kryminały zajmują główną pozycję pośród innych gatunków masowo czytanych. Niniejsze rozważania koncentrują się na przyczynach tak intensywnego rozwoju odmian gatunkowych kryminału, genezie oraz lokalnych uwarunkowaniach w obrębie kultury sowieckiej, następnie postsowieckiej, które doprowadziły do obecnego kształtu oraz roli rosyjskiej powieści sensacyjnej. Kluczowe pozostaje poszukiwanie odpowiedzi na pytanie o przyczyny tak wielkiej popularności tego typu prozy w społeczeństwie postsowieckim.

W kontekście historycznym wspomniane są specyficznie zmodyfikowane odmiany powieści sensacyjnej, jakie powstały w warunkach formowania kolektywnego społeczeństwa sowieckiego. Jest to powstały w opozycji do kryminału „,burżuazyjnego”, zmodyfikowany ideologicznie, tzw. czerwony kryminał (powieści Marietty Szaginian), a także funkcjonujące równolegle powieści sensacyjne pozorowane na dokument (opowiadania Lwa Szejnina, cykl o majorze Proninie Lwa Owałowa), sowieckie powieści szpiegowskie (autorstwa Juliana Siemionowa z jego kultową kreacją Stirlitza), następnie powieści milicyjne. W dalszej części artykułu zaprezentowana została krótka charakterystyka nowych, często hybrydowych odmian powieści kryminalnej w Rosji po upadku cenzury. Przywołane zostały takie nazwiska poczytnych autorów, jak Aleksandr Buszkow (gatunek: historia alternatywna), Edward Topol (thriller polityczny), Wiktor Suworow, Czyngiz Abdułłajew, Fridrich Nieznanski, Danił Korietski, Nikołaj Leonow (powieści sensacyjne, szpiegowskie, sensacyjne powieści historyczne), Roman Arbitman (thriller ironiczny, kryminał satyryczny). Ponadto scharakteryzowane zostały gatunki będące fenomenem sprzedażowym w Rosji lat dziewięćdziesiątych - tzw. bojewik, skierowane do męskiego odbiorcy (reprezentowany przez Wiktora Docenkę), oraz przeznaczony dla kobiet tzw. detektyw ironiczny (książki Darii Doncowej).
\end{abstract}


Końcowe wnioski zwracają uwagę na fakt, że powieści sensacyjne w ich wielości odmian gatunkowych we współczesnej Rosji pełnią także rolę społeczną, stanowiąc specyficzny komentarz do wydarzeń bieżących. Opisują nową rzeczywistość postsowiecką i pomagają czytelnikowi masowemu zaadaptować się do nowych warunków. Pełnią funkcję kompensacyjną, sprawiając pozór, że można odnaleźć po upadku byłego systemu poczucie utraconego ładu.

\section{Summary}

Present article describes the process of forming in Soviet Union and then in Russia a genre of crime novels. This is an attempt to answer the question about the reasons of so intensive development of different forms of detective genres, which became a sell-phenomenon after the collapsing of the Soviet regime. The purpose of this analysis is to consider, why this detective fiction is so desirable in post Soviet society.

In this paper there are mentioned the different Soviet forms of sensationalistic and detective genres, which were ideologically modified like the "red detective" ("red Pinkerton") in novels written by Marietta Shaginian; sensationalistic stories written in a documentary style (the novels by Lev Shejnin, the works of Major Pronin by Lev Ovalov), Soviet spy novels (Yulian Semyonov with his creation - Stirlitz, who has become a cult figure for Russians), and militia detective stories (Arkadi, Georgi Vainer with the famous character of Gleb Zheglov). Therefore the article presents the short characteristic of new, even hybrid form of detective fiction in Russia after the abolition of the censorship. In that time there had appeared and become very popular thrillers or political detective stories (Aleksandr Bushkov - alternative history, Eduard Topol - political thriller, Viktor Suvorov, Chyngiz Abdułłajev, Fridrich Nieznanski, Danił Korietski, Nikołaj Leonov - sensationalistic stories, spy novels, sensationalistic historical stories, Roman Arbitman - ironic thriller, satirical detective stories, political fantastic). Moreover in Russia of the 90s the genre so called bojevik dedicated to male readers (Victor Dotsenko) and ironic detective - dedicated to female public (Daria Dontsova) had become commercial phenomenon.

The conclusion of the paper is that nowadays in Russia such different forms of sensationalistic stories have started to play the social role like a specific commentary on the current events. They give a description of the new post Soviet reality. They help the mass readers to adopt themselves to the new circumstances, to experience some "positive stress". Therefore this kind of literature has a therapeutic influence. Studying different cases of popular fiction helps to understand the character of all social changes after 1991st in Russia and in some way shows how new identities are formed.

Słowa kluczowe: kryminał, społeczeństwo postsowieckie, gatunek sensacyjny, „czerwony kryminal", bojevik

Keywords: detective fiction, post Soviet society, sensationalistic genre, "red detective", bojevik

Rozważania nad powieścią kryminalną, która w Rosji postsowieckiej zyskała sobie dużą popularność, należy rozpocząc od rozróżnienia dwóch sposobów postrze- 
gania i definiowania samej formy gatunkowej. W pierwszym - wąskim rozumieniu - kryminał posiada rygorystyczną kompozycję i podlega określonym zasadom na poziomie struktury tekstu. John Cawelti, unikając pejoratywnych określeń literatury popularnej, wprowadza pojęcie „literatura formułowa” czy też „literatura formul”. Zwraca on uwagę na specyfikę takiego rodzaju utworów, jak romans historyczny, powieść miłosna, kryminalna, humorystyczna, western czy thriller, w których z założenia utrwalany jest określony kanon standardowych rozwiązań kompozycyjnych w obrębie poszczególnych „formul”. Wówczas istotne jest zagadnienie realizacji samego gatunku na tle uwarunkowań kulturowych oraz tradycji literackich. Wobec powyższego założenia sposób wykorzystania zestawu zdefiniowanych atrybutów pozwala na ocenę jakości danego kryminału w obrębie zadanej formuły. W takim zawężonym rozumieniu, akcentującym aspekt genologiczny - osią konstrukcji powieści kryminalnej pozostaje zagadka logiczna, przygoda intelektualna, której celem jest zidentyfikowanie sprawcy zbrodni. Wówczas gatunek ów przybiera znamiona bardziej koneserskie, „smakowany” jest w kręgach znawców poddających analizie konstrukcję określonej powieści. Dowodem na to może być na przykład Międzynarodowy Festiwal Kryminału (który w 2015 r. odbył się po raz dwunasty we Wrocławiu) ${ }^{2}$ czy też przyznawana od 2004 r. Nagroda Wielkiego Kalibru za najlepszą polską powieść kryminalną.

Drugie podejście charakteryzuje klasyfikacja tekstu jako kryminału w oparciu o niezmienny element, jakim jest obecność przestępstwa, czy też nawet samej tajemnicy niebezpiecznej i zagmatwanej zbrodni, obudowywanej w konteksty społeczne, polityczne, historyczne. W tym przypadku granice gatunkowe powieści kryminalnej ulegają bezustannym rozszerzeniom, a zasięg oddziaływania oraz poczytność tego typu literatury stają się bardziej powszechne, bywa, że nawet masowe. Właśnie taka sytuacja wytworzyła się na gruncie rosyjskim, gdzie w perspektywie historycznej i kulturowej gatunkowi kryminału została wytyczona początkowo specyficzna rola ideologiczna, a następnie - po upadku Związku Radzieckiego - nastapiło uwolnienie od podległości odgórnym wytycznym. W rezultacie, jak stwierdza między innymi Natalia Praszczeruk, miała miejsce „detektywizacja całego kraju i prozy”’. We współczesnej Rosji kryminały zajmują główną pozycję pośród innych gatunków masowo czytanych. Borys Dubin w swoich badaniach dowodzi, że rodzima literatura sensacyjna wyparła thumaczone romanse ${ }^{4}$. Potwierdza taką diagnozę Władimir Bieriezin,

${ }^{1}$ Zob. J. G. Cawelti, Kultura masowa. Formuły, gatunki i archetypy, przeł. A. Fulińska, „Znak” R. 48, 1996, nr 10, s. 125.

${ }^{2}$ Zob. Międzynarodowy Festiwal Kryminału od wtorku, http://www.wroclaw.pl/miedzynarodowyfestiwal-kryminalu-2015 (dostęp: 20.05.2015).

${ }^{3}$ Н. В. Пращерук, «Детективизация» современной прозы: к вопросу об онтологии проиесса [w:] Культ - товары. Феномен массовой литературы в современной России. Сборник научных статей, сост. И. Л. Савкина, М. А. Черняк, Санкт-Петербург 2009, s. 181.

${ }^{4}$ Zob. Б. Дубин, Средняя литература для среднего человека, „Русский Журнал”, http://old. russ.ru/krug/20010911.html (dostęp: 26.01.2015). 
twierdząc, że w zderzeniu z dynamicznym rozwojem utworów sensacyjnych rosyjska powieść miłosna nie zaistniała w postaci projektu komercyjnego ${ }^{5}$. W okresie burzliwych przemian lat dziewięćdziesiątych wydawnictwo Eksmo, dzięki decyzji o skoncentrowaniu się na rodzimej beletrystyce sensacyjnej (publikacji takich autorów, jak Danił Korieckij czy Czyngiz Abdułłajew), zajęło pierwsze miejsce na rosyjskim rynku książki. Nasuwa się pytanie o przyczynę tak intensywnego rozwoju odmian gatunkowych kryminału na tym obszarze oraz o genezę i uwarunkowania lokalne w obrębie rozwoju kultury początkowo sowieckiej, następnie postsowieckiej, które do obecnego kształtu oraz roli powieści sensacyjnej w Rosji doprowadziły.

Odmienne funkcjonowanie oraz miejsce zajmowane przez tego typu literature w rosyjskiej kulturze przełomu XX i XXI w. ściśle związane jest z tłem historycznym, charakterem rzeczywistości sowieckiej, która narzuciła specyficzną drogę rozwoju gatunkowego również i odmianom powieści sensacyjnej. W minionym systemie, w którym funkcjonowała, jak mówi Wojciech Kajtoch - estetyka treści, nie formy ${ }^{6}$, gatunek kryminału uległ modyfikacji ideologicznej, w wyniku której ukształtowały się oryginalne odmiany powieści kryminalno-awanturniczo-szpiegowskiej, takie jak czerwony kryminał ${ }^{7}$ czy też powieść milicyjna. Zgodnie z wytyczonym przez ówczesne prawo kierunkiem przestępstwa kryminalne kwalifikowano do sfery wykroczeń politycznych. Wówczas gatunek ten stał się skutecznym środkiem ideowego i moralnego oddziaływania na ludzi, a nawet narzędziem walki propagandowej.

Czerwony kryminał stał się próbą stworzenia sowieckiej powieści sensacyjnej stojącej w opozycji do kryminału „burżuazyjnego” oraz parodiującej jego wzorce. W roku 1924 ukazała się wydana pod pseudonimem Dżimm Dollar powieść Marietty Szaginian Mess-Mend (Месс-Менд). We wstępie znalazły się rozważania teoretyczne autorki określające wytyczne dla powieści zwanej „czerwonym pinkertonem”, której celem miało być wykorzystanie klisz i schematów kryminałów zachodnioeuropejskich $\mathrm{w}$ walce $\mathrm{z}$ niszczycielskimi siłami imperializmu oraz faszyzmu lat dwudziestych $\mathrm{XX}$ w. ${ }^{8}$ Główny bohater powieści to amerykański robotnik, założyciel związku robot-

${ }^{5}$ Zob. В. Березин, Импорт иронии. Польский след русской массовой культурьы, „Независимая газета", Ex libris, 22.05.2003, № 17, s. 7.

${ }^{6}$ Zob. W. Kajtoch, Socrealizm jako sposób myślenia o literaturze [w:] Proza, proza, proza ... (opowiadania, fragmenty, eseje, notatki), t. 3, wyb., wstęp i red. W. Kajtoch, Kraków 1997, s. 328.

${ }^{7}$ Zob. Р. Нудельман, Фантастика, рожденная револючией, „Фантастика” 1966, Вып. 3, Москва 1966, http://www.fandom.ru/about_fan/nudelman_3.htm (dostęp: 20.01.2015). O czerwonym kryminale wspominają także Wojciech Kajtoch w rozprawie poświęconej braciom Strugackim, przyporządkowując go do nisko cenionego przez ówczesną krytykę nurtu rozrywkowego, oraz Maria Czerniak w części swej pracy, poświęconej ewolucji gatunku powieści awanturniczej lat dwudziestych XX w. i kierunkom rozwoju rosyjskiej literatury masowej. Zob. W. Kajtoch, Bracia Strugaccy (zarys twórczości), Kraków 1993, s. 22; М. А. Черняк, Феномен массовой литературы ХХ века: монография, Санкт-Петербург 2005, s. 85-86, 88.

${ }^{8}$ Zob. М. Шагинян, Как я писала Месс-Менд [w:] еadem, Месс-Менд, или янки в Петрограде, Москва 1979, s. 285-86. 
niczego Mess-Mend, rozpoczynającego walkę z faszyzmem i przeciwnikami idei socjalistycznej. W książce, opatrzonej podtytułem ,powieść-bajka”, nie brakuje elementów fantastycznych w postaci ożywionych przedmiotów pomagającym robotnikom w walce (samootwierające się zamki w drzwiach, podsłuchujące ściany, ukrywające schowki). W krótkim czasie powstały reprezentujące gatunek ,czerwonego pinkertona” takie utwory, jak Trest DE. Historia upadku Europy (Трест Д.Е. История гибели Eвропы, 1923) Ilji Erenburga, Wyspa Erendorff (Остров Эрендорф, 1924), Władca żelaza (Повелитель железа, 1925) Walentina Katajewa, a także Lori-Len, metalowiec (Лори-Лен металлист, 1925) wspomnianej Marietty Szaginian.

Odrębną ówczesną drogą rozwojową ,czerwonego kryminału”, obok zbudowanej na zasadzie kontrastu figury wroga w myśl walki propagandowej, staje się praktyka tworzenia historii sensacyjnych, zabarwianych aurą autentyczności. Przykładem korzystania z takiej metody twórczej jest Lew Szejnin, który posiadał szerokie doświadczenie jako kryminolog (zajmował stanowisko sędziego śledczego oraz naczelnika wydziału śledczego w Związku Radzieckim do roku 1950). Bazując na własnych doświadczeniach pracy w prokuraturze jako materiale dla twórczości literackiej, stworzył on zbiór opowiadań i szkiców Notatki sędziego śledczego (Записки следователя, 1938). W jego skład weszły różnorodne teksty, które przez pryzmat wykroczeń barwnie opisywały zróżnicowane środowiska, a także regiony tworzącego się państwa komunistycznego, niosąc jednocześnie odpowiednie przesłanie ideologiczne9.

Inny pisarz, Lew Owałow, postanowił z kolei dokonać stylizacji swojego tekstu literackiego na szkic autentyczny. W roku $1940 \mathrm{w}$ serii „Biblioteka Czerwonoarmisty” („Библиотека красноармейца”) ukazała się jego książka Opowiadania majora Pronina (Рассказы майора Пронина). Sam autor zapewniał, że opowiadania te są zapisem słów tytułowego majora, rzekomo realnie istniejącego człowieka ${ }^{10}$. W rzeczywistości była to kreacja literacka bohatera nowego typu - czekisty, kontrwywiadowcy walczącego o interesy nowo powstałego państwa. Popularność Pronina zwielokrotniły dowcipy oraz anegdoty, które przyczyniły się do stworzenia jego mitu w kulturze tamtych dziesięcioleci. Wedle słów Arsenija Zamostjanowa był to wówczas jeden $\mathrm{z}$ niewielu bohaterów literackich od początku zaprojektowany zgodnie z regułami odpowiadającymi tradycji kultury masowej ${ }^{11}$. Według rosyjskiego klasyka literatury

${ }^{9}$ Jeden ze szkiców ukazuje zepsucie moralne żon nepmanów pracujących w domu schadzek, w innym Lapończycy z entuzjazmem odnoszą się do bolszewików. Zob. L. Szejnin, Notatki sędziego śledczego, przeł. A. Galis, I. Szenfeld, Warszawa 1961.

${ }^{10} \mathrm{~W}$ skład książki Opowiadania majora Pronina (Рассказы майора Пронина, 1939) weszły teksty: Błękitne miесzе (Синие мечи), Zimowe wakacje (Зимние каникуль), Bajka o tchórzliwym czorcie (Сказка о трусливом чёрте). Na późniejszą pozycję Opowiadania o majorze Proninie (Pacсказы о майоре Пронине, 1940) złożyły się teksty: Kury Dusi Cariewny (Куры Дуси Царевой), Agave mexican oraz Szklanka wody (Стакан воды).

${ }^{11}$ Zob. A. Замостьянов, Пронинское ассорти, Герой массовой литературы в соиио-культурном контексте, http://anguium.narod.ru/major_Pronin_2.html (dostęp: 20.02.2015). 
detektywistycznej, Gieorgija Wajnera, książka o majorze Proninie w swoim czasie była jeśli nie jedyna, to jedną z niezmiernie rzadkich masowo-poczytnych pozycji ${ }^{12}$. Następnie w roku 1941 ukazało się opowiadanie szpiegowskie Lwa Owałowa Btękitny aniol (Голубой ангел), w którym jeden z epizodów przedstawia działalność kontrwywiadu sowieckiego. Utwór ten z jednej strony zapewnił pisarzowi wielką popularność, z drugiej natomiast spowodował wysunięcie wobec niego oskarżeń o zdradzanie metod pracy operacyjnej sowieckich służb specjalnych. Lew Owałow zapłacił za swoje opowiadania ośmioma latami obozu oraz siedmioma latami zesłania. W $1958 \mathrm{r}$. pisarz został zrehabilitowany i, co istotne, zdecydował się na kontynuację cyklu o popularnym bohaterze.

Kryminał w Związku Sowieckim aż do czasów odwilży lat sześćdziesiątych był niemal wyłącznie kryminałem szpiegowskim. Pośród gatunków sensacyjnych królowały wówczas propagandowe powieści wojenne oraz szpiegowskie, na co bezsprzeczny wpływ miało doświadczenie wielkiej wojny ojczyźnianej oraz atmosfera zimnej wojny. Podobne gatunki łączyły w sobie z jednej strony stylizację dokumentalna, z drugiej - fikcję z elementami fantastycznymi oraz kryminalnymi. Wartka akcja sensacyjna, wciągając czytelnika, miała jednocześnie wpływać na pogłębienie uczuć patriotycznych.

Dominującymi hasłami propagandy wojennej, jakie znalazły odzwierciedlenie w kształtującej się w Związku Sowieckim odmianie powieści sensacyjnej, były: spisek, wywiad, kontrwywiad, szpiegostwo. Michaił Heller podkreśla znaczenie tajemnicy w społeczeństwie sowieckim. Mówi o „rytuale tajemniczości”, który na przeciętnego człowieka ma wpływ wychowawczy. W takim kontekście wzrastała waga informacji, zdobywanej przez wywiad, a agent zaczynał być postrzegany jako ideał człowieka sowieckiego ${ }^{13}$. Jak podaje Arsenij Zamostjanow, wątek szpiegowski przeniknął i utrzymał się nawet w późniejszych kryminałach milicyjnych z czasów Chruszczowa, w których przestępcy występują jako najniebezpieczniejsi szpiedzy ${ }^{14}$. Przykładem może tu posłużyć cieszące się niemałą popularnością opowiadanie Matwieja Rojzmana z 1956 r. Sprawa nr 306 (Дело № 306), na podstawie którego nakręcono w tym samym roku film, okrzyknięty pierwszym kryminałem sowieckim (w roku premiery obejrzała go rekordowa liczba 33,5 mln widzów ${ }^{15}$ ), a także utwór Arkadija Adamowa Sprawa pstrokatych (Дело пестрых, 1956), zekranizowany w roku 1958. Sprawa $n r$ 306 przedstawia sposób, w jaki funkcjonariusze milicji w awanturze ulicznej demaskują działalność agentów obcego wywiadu. Typowy finał podobnych incydentów

${ }^{12}$ Zob. wypowiedź Gieorgija Wajnera w programie radiowym Piotra Wajla, П. Вайль, Майор Пронин, http://www.svoboda.org/content/transcript/24204534.html (dostęp: 20.01.2015).

${ }^{13}$ Zob. M. Heller, Maszyna i śrubki. Jak hartowat się człowiek sowiecki, Warszawa 1989, s. 66-67.

${ }^{14}$ Zob. А. Замостьянов, Золотые дни майора Пронина, http://anguium.narod.ru/major_Pronin_6.html (dostęp: 20.01.2015).

${ }^{15}$ Дело № 306, www.nashekino.ru/data.movies?id=1354 (dostęp: 28.01.2015). 
wyglądał często tak, że specjaliści z Pietrowki ${ }^{16}$ wypełniali swą część zadania, a następnie przekazywali sprawę „,do specjalnego rozpatrzenia” w KGB ${ }^{17}$.

W latach pięćdziesiątych ubiegłego wieku zaczęła konstytuować się w Związku Radzieckim specyficzna odmiana literatury kryminalnej, określana mianem kryminału milicyjnego ${ }^{18}$. Jej specyfiką był opis działań pracowników aparatu państwowego i, co typowe, owi „detektywi”, czyli oficerowie śledczy, nie działali samodzielnie, ale jedynie w otoczeniu współpracowników oraz przy wsparciu odpowiedniego zaplecza instytucjonalnego. Na przełomie lat pięćdziesiątych i sześćdziesiątych tematyka milicyjna pojawiła się w książkach Arkadija Adamowa, który jako jeden z pierwszych pisał o funkcjonariuszach wydziału kryminalnego. Następnie stworzył cykl powieściowy połączony postacią głównego bohatera - inspektora Witalija Łosjewa. Trylogia Inspektor Łosjew, składająca się z książek Złym wiatrem (Зльм ветром, 1973), Pętla (Петля, 1975) oraz Na wolne miеjsce (На свободное место, 1982) została nagrodzona Złotym Medalem im. Bohatera Związku Radzieckiego N. Kuzniecowa za najlepszy utwór heroiczno-przygodowy. Powieści te odbiegają jednak od gatunku kryminału, dlatego - być może - właściwsze byłoby określenie ich mianem „milicyjnej powieści produkcyjnej”.

Bardziej zróżnicowany rozwój gatunku kryminału w Związku Radzieckim rozpoczął się po śmierci Stalina, równolegle z wydaniem tłumaczeń na język rosyjski opowiadań Gilberta Chestertona w roku 1958 oraz powieści Georgesa Simenona w roku $1960^{19}$. Na przełomie lat sześćdziesiątych i siedemdziesiątych zadebiutowali tacy pisarze, jak Nikołaj Leonow - twórca słynnej kreacji śledczego Lwa Gurowa ${ }^{20}$ - bracia Arkadij i Gieorgij Wajnerowie - którzy bohaterem wielu swych opowiadań uczynili pracownika wydziału kryminalnego, Stasa Tichonowa ${ }^{21}$ - a także Eduard

${ }^{16}$ Pietrowka to potoczna nazwa moskiewskiej siedziby milicji, obecnego Głównego Zarządu Spraw Wewnętrznych, mieszczącego się w Moskwie przy ul. Pietrowka 38.

${ }^{17}$ Zob. А. Замостьянов, Золотые дни...

${ }^{18} \mathrm{O}$ rozwoju rosyjskiej powieści kryminalnej, w tym powieści milicyjnej, zob. A. Domogalla, Rosyjska powieść kryminalna XX-XXI wieku (Wokót przemian gatunkowych) [w:] Z przemian gatunkowych w literaturze rosyjskiej XX i XXI wieku, red. H. Mazurek, J. Gracla, Katowice 2008, Rusycystyczne Studia Literaturoznawcze, t. 20, s. 72-73.

${ }^{19}$ Pod koniec lat pięćdziesiątych pojawiają się takie nazwiska, jak: Aleksandr Awdiejenko, Georgij Briancew, Jurij Dold-Michajlik, Wiktor Michajłow, Leonid Płatow (Łomakin), Wadim Kożewnikow, Wasilij Ardamatskij, Aleksandr Nasibow, Stanisław Gagarin oraz wiele innych, którzy zaabsorbowali prozą sensacyjną uwagę czytelników. Zob. М. Хоста, А. Верховский, „Шпионский” роман (Попьытка краткого обзора), http://modernlib.ru/books/hosta_marina/shpionskiy_roman_popitka_kratkogo_ obzora/read (dostęp: 9.04.2015).

${ }^{20}$ To bohater spinający klamrą 28 powieści. Na kartach cyklu przechodzi ewolucję od niedoświadczonego chłopca do profesjonalnego detektywa. Zob. Николай Иванович Леонов, http://lib.rus.ec/a/7139 (dostęp: 9.05.2015).

${ }^{21}$ Ukazało się osiem powieści z tym bohaterem. Zob. A. Вайнер, Г. Вайнер, Следователь Тихонов, www.fantlab.ru/work270512 (dostęp: 9.05.2015). 
Chruckij, Anatolij Romow, Gielij Riabow i Aleksiej Nagornyj22. W szczególności w czasach odwilży, co podkreśla Birgit Mencel, znani autorzy ówczesnych odmian powieści kryminalnych starali się przeciwstawić zdyskredytowanej w Związku Radzieckim formie kryminału typu zachodniego sowiecki „kryminał wysoki”, w którym byłyby przedstawione normy moralne, charakterystyczne dla inteligencji tamtej epoki. Wiele kryminałów szpiegowskich oraz milicyjnych obrazowało swego rodzaju etos kulturalnego zachowania, jak to nazywa Birgit Mencel - „kulturalność”23.

$\mathrm{Z}$ początkiem lat sześćdziesiątych do literatury wszedł także Julian Siemionow (prawdziwe nazwisko Landries), który dekadę później wprowadził do swych powieści postać niezapomnianego agenta Stirlitza ${ }^{24}$. Książki tego jednego z najpoczytniejszych autorów stanowiły prawdziwy rarytas w czasach deficytu kryminałów zagranicznych. Wykorzystywał on zarówno wątki milicyjne, jak i szpiegowskie, wprowadzał różnorodność fabuł sensacyjnych oraz postaci, których życie ze względu na charakter ich zajęć było zajmujące - szlachetnych i odważnych lotników, geologów, milicjantów, wywiadowców, kontrwywiadowców. Stali się oni sztandarowymi postaciami sowieckiej literatury popularnej. W konstruowaniu bohaterów pisarz ten dbał o szczegół i wiarygodność, co osiagał dzięki wykorzystaniu materiałów z archiwów państwowych.

Pierwsza powieść polityczno-przygodowa Juliana Siemionowa Dyplomatyczny agent (Дипломатический агент) powstała w roku 1959, a jej akcja koncentrowała się wokół przygód badacza Wschodu - Witkiewicza, który był dyplomata, a zarazem tajnym agentem. Uznaniem publiczności cieszyła się także jego inna powieść szpiegowska Operacja „Żagiew” (ТАСС уполномочен заявить, 1977). Autor ten zyskał ogromną popularność również dzięki powieściom przedstawiającym życie codzienne funkcjonariuszy milicji sowieckiej - słynnemu, napisanemu w roku 1963, kryminałowi Pietrowka 38 (Петровка 38), powstałej w 1972 roku powieści Ogariewa 6 (Огарева 6) oraz późniejszej-Przeciwdziałanie (Противостояние, 1979). O роzусji tego twórcy jako autora prozy kryminalno-sensacyjnej świadczy fakt, że w 1986 r. został on przewodniczącym Międzynarodowego Stowarzyszenia Powieści Kryminalnej i Politycznej oraz głównym redaktorem periodyku „Kryminał i Polityka” (,Детектив

${ }^{22}$ Zob. М. Хоста, А. Верховский, ,Шпионский” роман...

${ }^{23}$ Б. Менцель, Что такое „популярная литература”? Западные концепции „высокого” и ,низкого” в советском и постсоветском контексте, пер. А. В. Маркина, „Новое литературное обозрение" 1999, № 40, s. 401.

${ }^{24}$ Maksima Maksimowicza Isajewa - Stirlitza, agenta sowieckiego działającego w kręgu najwyższego dowództwa Trzeciej Rzeszy Siemionow uczynił bohaterem 12 samodzielnych powieści tworzących cykl „Kroniki Polityczne” („Политические хроники”), w którego skład weszły m.in.: Brylanty dla dyktatury proletariatu (Бриллианты для диктатуры пролетариата, 1971), Hasła nie trzeba (Пароль не нужен, 1966), Alternatywa (Альтернатива, 1976), Trzecia karta (Третья карта, 1977), Major Wicher (Майор Bихр, 1967), Bотba dla przewodniczqcego (Бомба для председателя, 1970). Natomiast uwielbienie powszechne przyniosła autorowi kreacja Stirlitza z powieści Siedemnaście mgnień wiosny (Семнадйать мгновений весны, 1970), na podstawie której w 1973 r. został nakręcony dwunastoodcinkowy serial telewizyjny w reżyserii Tatiany Lioznowej z Wiaczesławem Tichonowem w roli głównej. 
и политика”), a także gazety „Ściśle Tajne” („Совершенно секретно”), której wydawanie zainicjował.

Ponieważ tematyka przestępczości w Związku Radzieckim była kwestionowana jako niestanowiąca problemu w raju, jaki miał stworzyć komunistyczny porządek społeczny, a literatura okresu powojennego podporządkowana została ,zasadzie bezkonfliktowości", w myśl której w społeczeństwie socjalistycznym zanikają antagonizmy, dlatego też autorzy zmodyfikowanych powieści kryminalnych dysponowali ograniczonym zestawem realizacji fabularnych. Zatem tym bardziej pociagające stawały się odmiany kryminału zachodniego, które w warunkach ich deficytu wyzwalały mocne emocje, ciekawość, wzmagając swą siłę oddziaływania poprzez efekt ,zakazanego owocu”. Tymczasem „kryminał zachodni”, niegdyś deprecjonowany jako „zgniłoburżuazyjny”, „mieszczański”, w rzeczywistości przedstawia sobą gatunek „miejski” - opisujący problemy życia w dużym konglomeracie urbanistycznym, w świecie wolnorynkowym. Przeznaczony on jest dla odbiorcy - mieszkańca miasta zachodniego, który czyta o niebezpieczeństwach kryjących się tuż obok niego, za rogiem. Czyta o własnych, niemal osobistych wrogach oraz o własnych obrońcach. W przeciwieństwie do rzeczywistości sowieckiej, w kryminale tym obnażane są jątrzące problemy, naświetlane niebezpieczne, odstręczające strony życia dużego miasta kapitalistycznego.

Taki właśnie układ życia społecznego odsłonił swoje oblicze po upadku Związku Radzieckiego, kiedy załamał się stary porządek. Wówczas z wielką intensywnością dały się odczuć problemy transformacji kulturowej, gospodarczej, kapitałowej. Owa gwałtowna zmiana sprzyjała pogłębiającym się kontrastom społecznym, rozkwitowi działalności przestępczej oraz wzrostowi zachłanności konsumenckiej warstw posiadających, zderzonej z wzmagającym się poczuciem frustracji tych, którzy nie potrafili zrozumieć i dostosować się do nowych mechanizmów i układów zależności. Jednym ze zjawisk towarzyszących transformacji ustrojowej w Rosji, w której osłabieniu ulegały struktury państwowe, była wzrastająca kryminalizacja życia. Procesy te znalazły także odzwierciedlenie w „kryminalizacji” oraz w ,industrializacji”25 literatury z intensywnym rozwojem form zwanych po rosyjsku dietiektiwy (kryminały). Jednocześnie diametralnej przemianie uległy środki masowego przekazu oraz style emitowanych komunikatów medialnych, których nieodłączną częścią stały się sensacja, zbrodnia, demaskowanie ciemnych stron życia i problemów socjalnych.

$\mathrm{Na}$ ewolucję gatunkową rodzimych kryminałów oddziaływały intensywnie także czasy „głasnosti” wraz z sukcesem na przełomie lat osiemdziesiątych i dziewięćdziesiątych w literaturze wysokoartystycznej tzw. czеrnисhy (чернуха), która stanowiąc jeden z bardziej popularnych gatunków literatury okresu pieriestrojki, wedle słów Alek-

${ }^{25} \mathrm{Na}$ temat owego przewrotu w dziedzinie literatury oraz jej „kryminalizacji” w warunkach realizmu rynkowego zob. В. Куприянов, Рыночный реализм, „Литературная газета” 2002, № 39, www.lgz. ru/archives/html_arch/lg392002/Polosy/art7_1.htm (dostęp: 11.01.2015). 
sandra Gienisa, nosiła wcześniej ładniejszą nazwę - szkic fizjologiczny ${ }^{26}$. Stała się ona produktem rozpadu świadomości zideologizowanej, obfitując w spotęgowany naturalizm w ukazywaniu ciemnych stron życia człowieka i społeczeństwa oraz w opisywaniu seksualnych poczynań bohaterów. Takie aspekty bardzo szybko zdominowały również rosyjską telewizję oraz kulturę popularną. Bazując na owym ,zamówieniu społecznym”, wydawnictwo Eksmo w 1994 r. zapoczątkowało pierwszą rosyjską serię kryminałów „Czarny Kot” (,Черная кошка”). Kolejno zaczęły mnożyć się inne „,czarne cykle”: „Czarny Znak”, „Czarna Wrona”, „Czarna Rękawiczka”, „Czarny Kwadrat”, „Czarny Zygzak”, „Czarne Słońce”, „Czarna Pantera”, powstała nawet seria kryminałów dla dzieci „Czarne Kocię”. Równie liczebnie w połowie lat dziewięćdziesiątych zaczęły ukazywać się serie podkreślające w swej nazwie aspekt gatunkowy: „Godzina Kryminału”, „Kryminalny Projekt”, „Powieść Kryminalna”, „Kryminalny Talent”. Trzeci typ serii wydawniczych akcentował rosyjskość, wskazywał na zaadaptowanie wielu gatunków sensacyjnych na gruncie rodzimym, co znalazło swój wyraz w nazwach: „Rosyjski Projekt”, „Rosyjski Thriller”, „Rosyjskie Tajemnice”, „Rosyjskie Porachunki”, „Rosyjska Rzeźnia” czy „Sprawiedliwość po Rosyjsku”.

W kontekście kulturowym przełom lat osiemdziesiątych i dziewięćdziesiątych przyniósł swoistą modę na dokumentalizm, dociekanie prawdy, odkrywanie na nowo historii, demaskatorstwo, a nawet spekulacje co do przebiegu wydarzeń. Czasy Związku Radzieckiego obfitowały w wiele mitów, zakłamywanych danych, niewyjaśnionych kwestii, zagadek historycznych, faktów wartych ujawnienia i reinterpretacji, co stało się także wdzięcznym tematem dla powieści sensacyjno-kryminalnej. Jak stwierdza Nik Perumow, krytykując twórczość Wiktora Suworowa, w społeczeństwie rosyjskim mamy do czynienia z „łasym na sensacyjne demaskacje czytelnikiem”27. Z jednej strony w atmosferze dążenia do odkłamywania przeszłości, z drugiej - wobec napływu audiowizualnej kultury zachodniej oraz nastawienia na wyzwalanie emocji odbiorcy poprzez epatowanie sensacją zmianie ulega status „tajemnicy” w świadomości zbiorowej. W wymiarze filozoficznym „tajemnica” podlega racjonalizacji, w wymiarze popkulturowym natomiast zanika wobec stosowanej praktyki niwelowania wszelkiego tabu.

Na taką zmianę kulturową zareagowały powstające żywiołowo odmiany powieści sensacyjnej, które jednak oddalają się od formuły klasycznego kryminału i podlegają gatunkowej hybrydyzacji. Zagadka, wciagająca historia kryminalna, której przebieg należy zrekonstruować - owa „formuła” Caweltiego - stała się niewystarczająca. W Rosji współczesnej głównym wyróżnikiem gatunkowym stał się aspekt tematyczny - powieść sensacyjno-kryminalna niezmiennie koncentruje się wokół „problemu” zbrodni czy też działalności przestępczej, natomiast sposób ich zobrazowania i osa-

${ }^{26}$ Zob. А. Генис, Иван Петрович..., s. 104.

${ }^{27}$ Por. В. Камша, Николай Перумов против Виктора Суворова, http://perumov.com/interview/ print/print_27.html (dostęp: 7.03.2015). 
dzenia w ciągu fabularnym bywa bardzo zróżnicowany. Zarysowany zostaje kontekst psychologiczny lub społeczny, bez wyraźnej granicy między dobrem a złem, a przestępstwo stanowi składową ukazanego chaotycznego świata przemocy. Akcja często koncentruje się wokół działań wymierzonych przeciwko już zdefiniowanemu przestępcy w świecie obfitującym w wynaturzenia cywilizacyjne. Jak zauważa Olga Sławnikowa, obecnie w Rosji właściwie przestały powstawać kryminały w formie klasycznej, czyli takie, które wymagają przeprowadzenia operacji myślowej w celu rozszyfrowania przebiegu dokonanego przestępstwa ${ }^{28}$.

Rosyjscy czytelnicy szczególnie upodobali sobie gatunek, zwany najogólniej kryminałem - thrillerem politycznym, który obejmuje także współczesną odmianę rosyjskiego kryminału historycznego czy szpiegowskiego. Cechą wspólną nowo powstających - przemieszanych i hybrydowych form gatunkowych - jest ich sensacyjność, związek z kontekstem socjalnym oraz obecność aluzji do wydarzeń aktualnie się rozgrywających. Do najbardziej poczytnych reprezentantów różnorodnych form podgatunkowych należą Aleksandr Buszkow (historia alternatywna), Eduard Topol (thriller polityczny), Wiktor Suworow, Czyngiz Abdułłajew, Fridrich Nieznanski, Danił Koriecki, Nikołaj Leonow (powieść sensacyjna, szpiegowska, sensacyjna powieść historyczna), Roman Arbitman (pseudonim literacki Lwa Gurskiego, który ucieka się do takich odmian, jak thriller ironiczny, kryminał-pamflet, kryminał satyryczny, fantastyka polityczna), Wiktor Docenko (bojewik, czyli sensacyjna powieść akcji) ${ }^{29}$.

Na początku lat dziewięćdziesiątych na rosyjskim rynku wydawniczym niewątpliwie jednym z bardziej nośnych gatunków sensacyjnych, przeznaczonych dla odbiorcy męskiego, staje się wymieniony powyżej gatunek, zwany po rosyjsku bojewik ${ }^{30}$. Wyrasta on z inspiracji amerykańskim czarnym kryminałem i proponuje nowy typ bohatera - słowiańskiego macho, który samodzielnie wartościuje i wymierza sprawiedliwość. Bojewik z jego tematyką polityczną oraz typem silnego bohatera-macho był gatunkiem wychodzącym naprzeciw stereotypowym męskim pragnieniom, by niezależnie i indywidualnie, a zarazem w sposób zdecydowany, stawić czoła chaotycznej rzeczywistości, która zaczęła nasiąkać wzorami eksportowanymi z amerykańskiego kina akcji. Ta nowa odmiana gatunkowa to rodzaj thrillera, w którym ścierają się rosyjskie służby specjalne z potężnymi i wpływowymi strukturami mafijnymi w Rosji i za granica, współpracując albo rywalizując ze służbami zachodnimi, w szczególności amerykań-

${ }^{28}$ Zob. О. Славникова, Супергерои нашего времени, „Знамя” 1998, nr 12, http://magazines.russ. ru/znamia/1998/12/slav.html (dostęp: 1.02.2015).

${ }^{29}$ Błyskawiczny sukces komercyjny osiagnną wydany w 1989 r. pierwszy bojewik autorstwa Wiktora Docenki - Wyrok dla Szalonego (Срок для Бешеного) - inicjujący jedną z dłuższych popularnych serii (w roku 2006 ukazała się jubileuszowa, trzydziesta część), której głównym bohaterem jest Sawielij Kuzmicz Goworkow o pseudonimie Szalony (Bieszenyj).

${ }^{30}$ Gatunek ten w kontekście socjologicznym rozpatruje Borys Dubin. Zob. Б. Дубин, Испытание на состоятельность. К сочиологической поэтике русского романа-боевика, „Новое литературное обозрение" 1996, № 2, s. 252-274. 
skimi. Przestępca jest określony, świat przedstawiony cechuje okrucieństwo i agresja. Dominantę kompozycyjną bojewika stanowi nieustanna walka bohatera heroicznego - obowiązkowo mężczyzny, który nosi piętno traumy i cierpienia. Powtarzającymi się elementami jego biografii są: fakt utraty rodziców we wczesnym dzieciństwie oraz wychowanie w domu dziecka, przeszłość wojenna - okrutne doświadczenia czy to wojny w Afganistanie w latach 1979-1989, czy też walk z Czeczenami. Gatunek ten, wedle spostrzeżeń Wiktora Miasnikowa, wprawdzie propaguje indywidualizm oraz kult siły w stylu amerykańskim, ale jednocześnie wydaje się mieć wiele wspólnego z literaturą heroiczno-patriotyczną oraz epopeją produkcyjna, wypełniając lukę powstałą po odejściu eposu sowieckiego ${ }^{31}$. Birgit Mencel odnotowuje jego poszczególne modyfikacje w stosunku do kryminału epoki sowieckiej ${ }^{32}$ : bohater bojewika samodzielnie tropi przestępcę czy też dokonuje aktu zemsty, ale nie przynależy już do kolektywu milicyjnego, nie jest przykładem czystego moralnie i świadomego milicjanta. Kieruje się własną skalą wartości, wykorzystuje swoją siłę fizyczną a granice pomiędzy moralnością i przemocą, dobrem i złem stają się relatywne.

Zjawiskiem charakterystycznym dla kryminału postsowieckiego jest powstanie na gruncie rosyjskim szeroko reprezentowanej „kobiecej” odmiany prozy sensacyjnej. W jej obrębie wykształciły się własne podgatunki, które stały się popularną lekturą milionów czytelniczek. W szczególności na początkowym etapie gwałtownej ewolucji powieści kryminalnej po roku 1991 w Rosji daje się zauważyć dyferencjacja płciowa, która jaskrawo zarysowuje się w poszczególnych utworach. Warunkuje ona sposób kreacji określonego bohatera i realizacji wątku kryminalno-sensacyjnego, wybór tematyki, a nawet warstwę stylistyczną powieści. Tę pierwszą fazę ewolucji po upadku Związku Radzieckiego cechowała walka o usankcjonowanie autorek, które w poprzednim układzie zostały wyeliminowane jako twórcy prozy sensacyjnej.

Wydawnictwo Eksmo w 1993 r. zdecydowało się na publikację książek Aleksandry Marininy (prawdziwe nazwisko Marina Anatolewna Aleksiejewa), pierwszej i do roku 1998 jedynej kobiety w serii „Czarny Kot”, która prezentowała utwory najbardziej znanych twórców kryminałów. Symptomatyczne jest, że powtarzającym się problemem na kartach powieści tej autorki, naświetlanym przez pryzmat jej bohaterki, Anastazji Pawłowny Kamieńskiej, jest nierówność w układzie ról damsko-męskich zarówno w płaszczyźnie życia prywatnego, jak i zawodowego w patriarchalnym i hierarchicznym społeczeństwie. Marinina niejednokrotnie podkreśla, że przeniosła na kreację inteligentnej pani major - śledczego milicji, własne doświadczenia zmagań o szacunek i odpowiednią pozycję dla kobiety w zdominowanych przez mężczyzn kręgach ministerialnych bądź w służbach ochrony prawa i porządku. Do roku 1995 ukazało się aż dziewięć powieści tej autorki w gatunku kryminału milicyjnego z bohaterką Kamieńską. Aleksandra Marinina (pseudonim ten szybko stał się marką hand-

${ }^{31}$ Zob. В. Мясников, Бульварный эпос, „Новый мир” 2001, № 11, s. 155.

${ }^{32}$ Zob. Б. Менцель, Что такое „популярная литература”? ..., s. 402. 
lowa), a następnie Polina Daszkowa ${ }^{33}$, uprawiająca kryminał psychologiczny, są pierwszymi autorkami, których książki wydawnictwa Eksmo i Ast zaczęły wydawać na szeroką skalę.

„Feminizacja” gatunku kryminału doprowadziła do stworzenia przez Eksmo w 1999 r. debiutanckiej serii „Kryminał w Oczach Kobiety”, w której ukazały się powieści takich reprezentantek rodzimych, jak Tatiana Polakowa ${ }^{34}$, Tatiana Stiepanowa $^{35}$, Wiktoria Płatowa ${ }^{36}$ czy Polina Daszkowa. Pojawiła się ogromna liczba rodzimych autorek tworzących prozę detektywistyczna, skierowana do kobiet. Niemniej, jak zauważa Olga Sławnikowa, dokonując przeglądu kryminałów kobiecych klasy średniej takich autorek, jak Anna Małyszewa, Anna Daniowa, Marina Sierowa, Wiktoria Płatowa, Jelena Arsienijewa, Tatiana Polakowa, zarówno współczesny rosyjski męski thriller, jak i kryminał kobiecy daleko wykraczają poza ramy gatunkowe kryminału ${ }^{37}$.

Nową, typowo rosyjską odmiana, która zdominowała rynek czytelniczy w Rosji, stał się kobiecy kryminał ironiczny. Upowszechniła go zainspirowana twórczością Joanny Chmielewskiej Daria Doncowa, dedykując tego typu prozę zwykłym rosyjskim kobietom jako ucieczkę od codzienności. Również w 1999 r. wydawnictwo Eksmo zaproponowało i rozpropagowało serię „Kryminał Ironiczny”, rozpoczynając ją od prezentacji książek Tatiany Polakowej, a następnie publikując w niej powieści Darii

${ }^{33}$ Polina Daszkowa (prawdziwe nazwisko Tatiana Wiktorowna Polaczenko) zadebiutowała w $1997 \mathrm{r}$. książką Krew nienarodzonych (Кровь нерожденных). Pośród jej licznych powieści część kwalifikowana jest do gatunków kryminalnych, choć sama autorka za takie ich nie uznaje. Zob. Дашкова Полина, http://polina-dashkova.ru (dostęp: 7.02.2015). Łączny nakład jej książek do 2006 r. wyniósł około $30 \mathrm{mln}$ egzemplarzy. Zob. М. Крутов, Субботнее интервью: Полина Дашкова, http://www.svoboda.org/ content/article/24187796.html (dostęp: 1.02.2015). O popularności tej pisarki, w szczególności w Niemczech, zob. Т. Коростелева, Высокий рейтинг ,, низкого” жанра, www.pr.azov.net/archiv/2003/N_25/ sov.htm (dostęp: 7.01.2015).

${ }^{34}$ Autorka charakteryzowana jest jako twórczyni kryminału awanturniczego w Rosji. Zgodnie z wypowiedzią Tatiany Polakowej jej bohaterki są zwyczajnymi, przypadkowymi kobietami, „osobami z tłumu", ponieważ brakuje jej wiedzy i kompetencji, by uczynić je wiarygodnymi pracownikami prokuratury czy też służb śledczych, a konieczność korygowania i ciagłych konsultacji ograniczałaby jej swobodę twórczą. Zob. Е. Скобелева, Татьяна Полякова: „Я же всё выдумываю!”.

${ }^{35}$ Tatiana Stiepanowa jest z wykształcenia prawnikiem, podobnie jak Aleksandra Marinina, posiada doświadczenie jako śledczy w milicji. Obecnie pracuje w centrum prasowym Głównego Wydziału do spraw Wewnętrznych (GUWD) Okręgu Moskiewskiego. Pośród ponad 30 jej kryminałów niektóre charakteryzowane są jako thrillery mistyczne, a najnowsze oscylują nawet wokół gatunku horroru. O poszczególnych książkach zob.: Татьяна Степанова, http://lib.rus.ec/a/11999 (dostęp: 25.01.2015); Татьяна Степанова, http://stepanova2001.narod.ru/Vstuplenie.htm (dostęp: 12.03.2015).

${ }^{36}$ Wiktoria Płatowa ukończyła Moskiewski Instytut Filmowy jako scenarzystka, ale nie pracowała w zawodzie. Jako autor prozy sensacyjnej zadebiutowała w 1998 r. Ponad 20 jej książek charakteryzowanych jest jako gatunek kryminału psychodelicznego czy też thrillera psychologicznego. Zob. Buкmoрия Платова, www.platova.ru (dostęp: 12.03.2015); Виктория Платова, http://lib.rus.ec/a/9676 (dostęp: 12.03.2015).

37 Zob. О. Славникова, Самка детективообразного, www.ozon.ru/context/detail/id/200464/ (dostęp: 12.03.2015). 
Doncowej, które już w roku 2000 zajęły pozycje bestsellerów. Autorka ta stanowi fenomen komercyjny w Rosji ${ }^{38}$, mając na swym koncie do roku 2015 ponad 170 książek, z których większość zgrupowana jest w sześciu cyklach powieściowych ${ }^{39}$.

Rozważając przyczyny tak dynamicznie postępującego rozszerzania się granic oraz popularności powieści kryminalnej w Rosji postsowieckiej, warto zwrócić uwagę na nowe funkcje, jakie zaczęła pełnić beletrystyka sensacyjna. Służy ona mianowicie jako komentarz do wydarzeń bieżących. To tekst zamknięty w czasie, przeznaczony do czytania „tu i teraz”, tworzony na kształt rosyjskich gazet i czasopism bądź programów telewizyjnych, które także obfitują w sensacje i historie różnorodnych wykroczeń i zbrodni. Jak stwierdza Wiera Zwieriewa, badaczka współczesnej rosyjskiej kultury audiowizualnej, „milicja”, „praworządność”, „kryminał”, „struktury siłowe" - to kluczowe pojęcia wspólne dla oficjalnego bloku informacyjnego oraz rozrywki ${ }^{40}$.

W przeciwieństwie do innych gatunków formułowych (fantastyki, fantasy, powieści miłosnej) gatunek kryminału wpisał się w nową rzeczywistość postsowiecka, służąc jako jej specyficzny opis. Sprzyja temu realizowana w powieściach kryminalnych zasada reprezentacji realistycznej, rozwój akcji ciąży ku prawdopodobieństwu i wiarygodności. W opisie okoliczności popełnienia przestępstwa, zobrazowaniu świata powieści czerpiącego inspirację z otaczającej autora rzeczywistości rosyjskiej, przeważa sztafaż realistyczny. Zgodnie z poglądem Maxa Horkheimera, to właśnie zjawisko mimesis jest jednym z podstawowych czynników rozwoju kultury popularnej ${ }^{41}$. Z kolei kryminał, jak charakteryzuje go Bertolt Brecht, to „szczególny splot życia realnego"42. Popularność tej formy gatunkowej w warunkach kryminogennej rzeczywistości rosyjskiej tłumaczą słowa Aleksandry Marininy, która podkreśla, że

${ }^{38}$ Zob. И. Шевелев, О пользе мигрени, „Независимая газета”, www.ng.ru/saturday/2003-1114/13_dontsova.html (dostęp: 2.02.2012). Zob. także krytyczny artykuł Nikołaja Wostrikowa o kryminałach ironicznych Darii Doncowej, Н. Востриков, Лохотрон, www.russ.ru/krug/20030326_vos.html (dostęp: 20.03.2015) oraz bardziej wyważony w ocenie tekst Inny Ryżkowej, И. Рыжкова, Действуй, сестра!, „Русский Журнал”, http://old.russ.ru/krug/20030618_ir-pr.html (dostęp: 20.04.2015).

${ }^{39}$ Ze względu na rozbieżne dane trudno ustalić dokładną liczbę książek firmowanych nazwiskiem Doncowej. Jej oficjalna strona informuje o 177 tytułach zgrupowanych w sześciu cyklach. Zob. B гостяx у Дарьи Донцовой, www.dontsova.ru/library/ (dostęp: 10.04.2015). Od 2008 r. autorka oskarżana jest o plagiat. Zob.: Н. Ямницкая, Донцову обвинили в плагиате, „Взгляд Деловая газета”, http://www. vz.ru/society/2008/5/22/170103.html (dostęp: 10.04.2015); Кулинарный плагиат Дарьи Дониовой, www.livejournal.ru/themes/id/18597 (dostęp: 10.04.2015).

${ }^{40} \mathrm{Zob}$. В. В. Зверева, «Настоящая жизнь» в телевизоре. Исследования современной медиакультуры, Москва 2012, s. 76.

${ }^{41}$ [Za:] A. Gromkowska-Melosik, Badania kulturowe w perspektywie spolecznego konstruktywizmu (na przyktadzie kobiecości) [w:] Kultura popularna i (re)konstrukcje tożsamości, red. A. Gromkowska-Melosik, Poznań-Leszno 2007, s. 101.

42 А. Адамов, Мой любимый жанр - детектив, http://literra.websib.ru/volsky/1262 (dostęp: 20.03.2015). 
ludzie chcieli widzieć w książce obecne życie swojego kraju ${ }^{43}$. W powieściach sensacyjnych świat fikcyjny ukazywany jest jako istniejący obiektywnie, niezależnie od wyobrażenia autora, dlatego też dla odbiorcy jest on rozpoznawalny. Wówczas odbiór tego typu powieści przez czytelnika popularnego porównać można, zgodnie z metaforą Thomasa Pavela, $z$ odwiedzinami w pewnym ,świecie możliwym" 44 , u pewnych skądinąd znanych osób. Łatwość percepcji tekstów kryminałów, wciagające sensacyjne fabuły przy jednoczesnym wrażeniu aktualności ich treści przyczyniały się do masowej ich popularności w Rosji postsowieckiej. Dodatkowo ich obecność w rosyjskiej świadomości zbiorowej utwierdziły powstające bardzo licznie od końca lat dziewięćdziesiątych sensacyjne seriale telewizyjne o obrońcach porządku, które w przeważającej części są ekranizacjami popularnych serii książkowych. Intryga kryminalna przeplata się w nich z przedstawionym życiem codziennym zarówno milicjantów, jak i zwykłych ludzi. Stanowią one połączenie propagandy oficjalnej, tematu przestępstwa i rozrywki pop-kulturowej. Ich twórcy w anonsach i opisach podkreślają, że ukazują one wszystko ,jak w życiu”:

Плахов, Рогов и Любимов попадают как в комичные, так и в тяжелые, трагические ситуации. [...] Но повествование лишено ура-патриотизма и пафоса, оно максимально приближено к реальной обстановке, в которой несут свою службу обычные милиционеры ${ }^{45}$.

Kolejnym elementem, jaki należy uwzględnić w rozpatrywaniu przyczyn tak wielkiego popytu na tego typu formy gatunkowe po upadku Związku Radzieckiego, jest aspekt psychologiczny, związany z ich oddziaływaniem na szerokie grono odbiorców. Pomagają one w oswajaniu nowej rzeczywistości. Jak twierdzi Boris Dubin: „Массовая культура - это система символической адаптации к происходящим переменам" ${ }^{\prime 4}$. Stąd też powieść kryminalna, której świat przedstawiony jest zbieżny z otaczającymi czytelnika przeobrażającymi się realiami, dostarcza mu ,pozytywnych stresów” oraz pomaga w rozładowaniu napięć i lęków, w adaptacji do nowych warunków.

Biegun problemów odzwierciedlających się w świecie przedstawionym tych utworów, który także bezpośrednio sprzężony jest ze zmianami socjokulturowymi, jakie nastąpiły po upadku poprzedniego układu politycznego, to wzajemna relacja pomiędzy „Systemem” i odrębnym, zatomizowanym człowiekiem wraz z jego życiem prywatnym w warunkach niestabilnej sytuacji materialnej. W roli „Systemu” może występować machina państwowa, organy bezpieczeństwa, organy śledcze, więzienia, łagry czy też

${ }^{43}$ Wywiad z A. Marinina, Я не считаю себя профессионалом детективного жанра, http://content.online.ru/mpl/face? id=436 (dostęp: 20.03.2015).

${ }^{44}$ Przytoczenie za: A. Martuszewska, Światy (nie)możliwe powieści, Gdańsk 2001, s. 192.

${ }^{45}$ Anons serialu Mienty, cyt. za: В. В. Зверева, Настоящая жизнь в телевизоре. Исследания современной медиакультуры, Москва 2012, s. 70.

${ }^{46}$ Б. Дубин, Слово-письмо-литература, Москва 2001, s. 161. 
struktury przestępcze i mafijne. W opozycji natomiast stoi pojedynczy bohater pozostający poza tymi strukturami, który indywidualnie ustala zasady i sam wymierza sprawiedliwość. Tego typu postać pop-kulturowego bohatera aktywnego, niepokornego indywiduum prezentuje Sawielij Kuzmicz Goworkow o pseudonimie Szalony (Bieszenyj) - łącznikowy bohater z cyklu powieściowego Wiktora Docenki, czy też kultowy Brat - romantyczny killer Daniła Bagrowa z filmu Aleksieja Bałabanowa.

Istotne zadanie społeczne, jakie wypełnia wiele rosyjskich utworów kryminalnych, polega na ich funkcji terapeutycznej, która wpisuje się w nasilające się w Rosji XXI w. nurty nostalgizujące. Jednym z podstawowych konfliktów fabularnych w gatunku bojewika czy powieści milicyjnej Marininy, Korieckiego, Buszkowa, Abdułłajewa jest zderzenie dwóch modeli i dwóch moralności - „breżniewowskiej”, przewidywalnej i obecnie idealizowanej fazy życia sowieckiego z kryminalizowanym, rynkowym, agresywnym życiem nowym. W wypowiedziach bohaterki powieści Marininy - Nastii Kamieńskiej, w jej żarliwym proteście wobec zła świata współczesnego pobrzmiewają nuty nostalgii za czasami minionymi, kiedy pieniądz nie odgrywał roli pierwszoplanowej, a zwykłych ludzi jakoby wyróżniała większa wrażliwość na cierpienia innych oraz gotowość niesienia pomocy.

W polu rosyjskich gatunków sensacyjnych daje się wyróżnić liczna grupa utworów, w których główną rolę pełni bohater-śledczy - inteligent działający w obrębie grupy i pozostający w ramach „Systemu”, ale dostrzegający jego nieprawidłowości. Taki funkcjonariusz obdarzony jest krytyczną świadomością zachodzących przemian, ale jednocześnie w poczuciu bezradności podejmuje bezinteresowną działalność dla dobra społeczeństwa.

Коррумпированной Россией - страной финансовых афер, биржевых махинаций и кровавой уголовщины - успешно правят банкиры и депутаты до тех пор, пока не появляется Турецкий. Его нельзя обвести вокруг пальца, подкупить или шантажировать, ведь он умен, независим и честен. Неуязвимый Турецкий просто выполняет свой долг... ${ }^{47}$

Powstają kreacje idealizowanych śledczych - inteligentów, którzy balansują pomiędzy koniecznością ochrony porządku i struktur władzy (w ich praworządność częściowo i sami nie wierzą) a własnym pojmowaniem sprawiedliwości oraz wartości moralnych. Uosabiają oni tęsknotę zbiorowości za przewidywalnością i ładem społecznym oraz istnieniem jedynych uniwersalnych wartości, szanowanych przez cała społeczność.

W powieściach tych prezentowane są zarówno inteligenckie dochodzenia, jak i inteligenckie przestępstwa. Wówczas dominanta kompozycyjna, skoncentrowana

${ }^{47}$ Anons serialu Марш Туреиякого (2000). Tureckij, bohater cyklu książkowego Fridricha Nieznańskiego to śledczy do zadań specjalnych Rosyjskiej Prokuratury Generalnej, http://ruskino.ru/mov/96 (dostęp: 15.04.2015). 
wokół poszukiwania sprawcy zbrodni, rozszerzona zostaje na poszukiwanie przyczyn tej zbrodni - społecznych, psychologicznych, filozoficznych. Dla przykładu w kryminałach Marininy bardzo często obecny jest temat tajemniczego „zła”, „winy”, „grzechu”. W tego typu współczesnych rosyjskich sensacyjnych odmianach gatunkowych w osobie głównego bohatera - skromnego śledczego uobecniają się wyraźnie atrybuty inteligencji sowieckiej. Pośród nich dominuje przede wszystkim lekceważący stosunek do dóbr materialnych, pogarda dla bogactwa oraz osiagania korzyści osobistych jako celu w życiu, skromność prywatnej egzystencji, swego rodzaju ascetyzm, idealizowana służba społeczeństwu z wykorzystaniem zalet intelektualnych, ukierunkowanych na walkę ze złem - dokonywanie starań, by ująć przestępcę, nie skazać winnego, wesprzeć ofiarę. Rozpoznawalna powszechnie bohaterka Nastia Kamieńska to osoba dobra, sprawiedliwa, uwrażliwiona na drugiego człowieka, wyzbyta ze snobizmu, skromna i uczciwa w swej pracy funkcjonariusza milicji. Jest człowiekiem inteligentnym, wykształconym i świadomym - prezentuje model postawy, skontrastowany ze skorumpowaną władzą oraz systemem powiązań przestępczych. Taki wizerunek aktywnego inteligenta umocniły seriale telewizyjne - powstałe w $1998 \mathrm{r}$. obrazy o „piterskich mientach” Łarinie, Dukalisie, Wołkowie, Kazancewie, następnie - ekranizacje powieści Marininy z major Kamieńską i kryminałów Nieznańskiego ze śledczym Prokuratury Generalnej RF Aleksandrem Tureckim. Poczciwy milicjant jest głównym bohaterem produkcji filmowych, które cieszyły się wielkim sukcesem wśród telewidzów, takich jak Улицы разбитых фонарей potocznie Менты (1998-2010), Убойная сила (2000-1006, na motywach powieści Kiwinowa), Участок (2003), Москва. Центральный округ (2003), Сыщщики (2001-2006). Postaci te prezentowane są jako uosobienie supermana-everymana - zmagają się z trudnymi i niebezpiecznymi zadaniami, ale jednocześnie zanurzone są w znanej widzowi rosyjskiej codzienności - korzystają z transportu publicznego, mieszkają w skromnych mieszkaniach, umeblowanych w stylu sowieckim, często wymagających remontu, prowadzą dochodzenia w ciasnych gabinetach, niewyposażonych w nowoczesny sprzęt.

Podsumowując niniejsze rozważania o tak szeroko reprezentowanych obecnie w Rosji gatunkach prozy sensacyjnej, paradoksalnie, co warto podkreślić, jest ona literaturą optymizmu społecznego, która niesie pozytywny przekaz dla odbiorcy. Bohaterowie przekonują, że świat współczesny nie pozostaje bez dobrych ludzi, piętrzące się problemy da się rozwiązać, a zło pokonać. Utwory kryminalne pełnią zatem funkcję kompensacyjną, mogąc wyzwolić poczucie oczyszczenia, dać pozorne uspokojenie. Wrażenie ,przywrócenia ładu”, jakie pozostawia po sobie gatunek kryminału, staje się gwarancją porządku, w którego istnienie pragnie wierzyć odbiorca, co podkreśla Natalia Zorkaja ${ }^{48}$. Dlatego też istotniejsza staje się nie tyle sama kolizja kryminalna i koncentracja uwagi odbiorcy na odgadywaniu osoby sprawcy zbrodni, ile w szerszym

${ }^{48}$ Zob. Н. Зоркая, Проблемы изучения детектива. Опыт немецкого литературоведения, „Новое литературное обозрение” 1996, № 22, s. 76. 
kontekście rzeczywistości postsowieckiej - poczucie istnienia sprawiedliwości. W takim wymiarze kryminał służy także temu, by przywrócić stałość ontologiczną obecnemu rozchwianemu życiu przeciętnego Rosjanina, w szczególności przynależącego do pokolenia, które dorastało w czasach systemu minionego. Może służyć pomocą w społeczeństwie, które stworzone zostało jako masowe z jasnymi wytycznymi odgórnymi, a po upadku Związku Radzieckiego znalazło się w stadium traumy po rozpadzie.

\section{Literatura}

Cawelti J. G., Kultura masowa. Formuły, gatunki i archetypy, przeł. A. Fulińska, „Znak” R. 48, 1996, nr 10, s. 116-128.

Domogalla A., Rosyjska powieść kryminalna XX-XXI wieku (Wokół przemian gatunkowych) [w:] Z przemian gatunkowych w literaturze rosyjskiej XX i XXI wieku, red. H. Mazurek, J. Gracla, Katowice 2008, Rusycystyczne Studia Literaturoznawcze, t. 20, s. 71-82.

Gromkowska-Melosik A., Badania kulturowe w perspektywie spolecznego konstruktywizmu (na przykładzie kobiecości) [w:] Kultura popularna i (re)konstrukcje tożsamości, red. A. Gromkowska-Melosik, Poznań-Leszno 2007.

Heller M., Maszyna i śrubki. Jak hartowat się człowiek sowiecki, Warszawa 1989.

Kajtoch W., Bracia Strugaccy (zarys twórczości), Kraków 1993.

Kajtoch W., Socrealizm jako sposób myślenia o literaturze [w:] Proza, proza, proza... (opowiadania, fragmenty, eseje, notatki), t. 3, wyb., wstęp i red. W. Kajtoch, Kraków 1997.

Martuszewska A., Światy (nie)możliwe powieści, Gdańsk 2001.

Szejnin L., Notatki sędziego śledczego, przeł. A. Galis, I. Szenfeld, Warszawa 1961.

Адамов А., Мой любимый жанр - детектив, http://literra.websib.ru/volsky/1262 (dostęp: 20.03.2015).

Березин В., Импорт иронии. Польский след русской массовой культуры, „Независимая газета", Ex libris, 22.05.2003, № 17, s. 7.

Генис А., Иван Петрови умер, Москва 1999.

Дубин Б., Испытание на состоятельность. К соииологической поэтике русского романа-боевика, „Новое литературное обозрение” 1996, № 2, s. 252-274.

Дубин Б., Слово-письмо-литература, Москва 2001.

Дубин Б., Средняя литература для среднего человека, „Русский Журнал”, http:// old.russ.ru/krug/20010911.html (dostęp: 26.01.2015).

Замостьянов А., Золотые дни майора Пронина, http://anguium.narod.ru/major Pronin_6.html (dostęp: 20.01.2015). 
Замостьянов А., Пронинское ассорти, Герой массовой литературы в соиио-культурном контексте, http://anguium.narod.ru/major_Pronin_2.html (dostęp: 20.02.2015).

Зверева В. В., «Настоящая жизнь» в телевизоре. Исследования современной медиакультуры, Москва 2012.

Зоркая Н., Проблемы изучения детектива. Опыт немеикого литературоведения, „Новое литературное обозрение” 1996, № 22, s. 65-77.

Камша В., Николай Перумов против Виктора Суворова, http://perumov.com/ interview/print/print_27.html (dostęp: 7.03.2015).

Коростелева Т., Высокий рейтинг ,низкого” жанра, www.pr.azov.net/archiv/2003/ N_25/sov.htm (dostęp: 7.01.2015).

Куприянов В., Рыночный реализм, „Литературная газета” 2002, № 39, www.lgz. $\mathrm{ru} / \mathrm{archives} / \mathrm{html}$ arch/lg392002/Polosy/art7_1.htm (dostęp: 11.01.2015).

Менцель Б., Что такое „,поплярная литература”? Западные конщепщии ,, высокого” и ,низкого” в советском и постсоветском контексте, пер. А. В. Маркина, „Новое литературное обозрение” 1999, № 40, s. 391-407.

Мясников В., Бульварныий эпос, „Новый мир” 2001, № 11, s. 150-158.

Нудельман Р., Фантастика, рожденная револючией, „Фантастика” 1966, Вып. 3, Москва 1966, http://www.fandom.ru/about_fan/nudelman_3.htm (dostęp: 20.01.2015).

Пращерук Н. В., «Детективизация» современной прозы:: к вопросу об онтологии прочесса [w:] Культ - товары. Феномен массовой литературы в современной России. Сборник научных статей, сост. И. Л. Савкина, М. А. Черняк, Санкт-Петербург 2009.

Славникова О., Самка детективообразного, www.ozon.ru/context/detail/id/200464/ (dostęp: 12.03.2015).

Славникова О., Супергерои нашего времени, „Знамя” 1998, nr 12, http://magazines. russ.ru/znamia/1998/12/slav.html (dostęp: 1.02.2015).

Хоста М., Верховский А., „Шпионский” роман (Попьтка краткого обзора), http://modernlib.ru/books/hosta_marina/shpionskiy_roman_popitka_kratkogo_ obzora/read (dostęp: 9.04.2015).

Черняк М. А., Феномен массовой литературы ХХ века: монография, Санкт-Петербург 2005.

Шагинян М., Как я писала Месс-Менд [w:] eadem, Месс-Менд, или янки в Петрограде, Москва 1979.

Шевелев И., О пользе мигрени, „Независимая газета”, www.ng.ru/saturday/200311-14/13_dontsova.html (dostęp: 2.02.2012).

Ямницкая Н., Донщову обвинили в плагиате, „Взгляд Деловая газета”, http://www. vz.ru/society/2008/5/22/170103.html (dostęp: 10.04.2015). 